\title{
Blockade of voltage-gated sodium channels inhibits invasion of endocrine-resistant breast cancer cells
}

\author{
FATIMA H. MOHAMMED ${ }^{1}$, MAITHAM A. KHAJAH ${ }^{1}$, MING YANG $^{2}$, \\ WILLIAM J. BRACKENBURY ${ }^{2}$ and YUNUS A. LUQMANI ${ }^{1}$ \\ ${ }^{1}$ Faculty of Pharmacy, Kuwait University, Safat 13110, Kuwait; ${ }^{2}$ Department of Biology, \\ University of York, Heslington, York, YO10 5DD, UK
}

Received September 1, 2015; Accepted September 24, 2015

DOI: 10.3892/ijo.2015.3239

\begin{abstract}
Voltage-gated $\mathrm{Na}^{+}$channels (VGSCs) are membrane proteins which are normally expressed in excitable cells but have also been detected in cancer cells, where they are thought to be involved in malignancy progression. In this study we examined the ion current and expression profile of VGSC $\left(\mathrm{Na}_{\mathrm{v}} 1.5\right)$ in estrogen receptor (ER)-positive (MCF-7) and silenced (pII) breast cancer cells and its possible influence on their proliferation, motility and invasion. VGSC currents were analysed by whole cell patch clamp recording. $\mathrm{Na}_{\mathrm{v}} 1.5$ expression and localization, in response to EGF stimulation, was examined by western blotting and immunofluorescence respectively. Cell invasion (under-agarose and Matrigel assays), motility (wound healing assay) and proliferation (MTT assay) were assessed in pII cells in response to VGSC blockers, phenytoin (PHT) and tetrodotoxin (TTX), or by siRNA knockdown of $\mathrm{Na}_{\mathrm{v}} 1.5$. The effect of PHT and TTX on modulating EGF-induced phosphorylation of Akt and ERK1/2 was determined by western blotting. Total matrix metalloproteinase (MMP) was determined using a fluorometric-based activity assay. The level of various human proteases was detected by using proteome profiler array kit. VGSC currents were detected in pII cells, but were absent in MCF-7. Na $\mathrm{N}_{\mathrm{v}} 1.5$ showed cytoplasmic and perinuclear expression in both MCF-7 and pII cells, with enhanced expression upon EGF stimulation. Treatment of pII cells with PHT, TTX or siRNA significantly reduced invasion towards serum components and EGF, in part through reduction of P-ERK1/2 and proteases such as cathepsin E, kallikrein-10 and MMP-7, as well as total MMP activity. At high concentrations, PHT inhibited motility while TTX reduced cell proliferation. Pharmacological or genetic blockade of $\mathrm{Na}_{\mathrm{v}} 1.5$ may serve as a potential anti-metastatic therapy for breast cancer.
\end{abstract}

Correspondence to: Professor Yunus A. Luqmani, Faculty of Pharmacy, Kuwait University, Safat 13110, Kuwait

E-mail: yunus@hsc.edu.kw

Key words: breast cancer, endocrine resistance, voltage-gated $\mathrm{Na}^{+}$channels, Nav1.5, phenytoin, tetrodotoxin, invasion, matrix metalloproteinase

\section{Introduction}

Breast cancer is the most frequently diagnosed neoplasm in women. In the majority of cases, hormonal manipulation by chemical or surgical oophorectomy, or by pharmacological intervention with anti-estrogens such as tamoxifen, remains one of the most effective approaches in the treatment of estrogen receptor (ER)-positive breast malignancies $(1,2)$. Both de novo and acquired resistance to endocrine based therapies results from actual or functional loss of ER and is paralleled by cellular transition from an epithelial to a mesenchymal phenotype. Commonly referred to as EMT, this is associated with enhanced proliferative and invasive capacity and results in poor clinical outcome.

Voltage-gated sodium channels (VGSCs) are heteromeric membrane protein complexes containing a single pore-forming $\alpha$ subunit and one or more smaller auxiliary $\beta$ subunits (3-7). They are classically responsible for initiation and propogation of action potential in excitable cells (8). They effect rapid $\mathrm{Na}^{+}$ influx coincident with efflux of intracellular $\mathrm{K}^{+}$. In mammals, ten genes encoding VGSC $\alpha$ have been described, nine of which constitute one family with designations of $\mathrm{Na}_{\mathrm{v}} 1.1$ to $\mathrm{Na}_{\mathrm{v}} 1.9$, and $\mathrm{Nax}(4,6,9-14)$. These isoforms are encoded by the genes SCN1A to SCN11A. VGSC $\alpha$ forms an ion pore that differs in its tetrodotoxin (TTX) sensitivity; being sensitive to either nanomolar $\left(\mathrm{Na}_{\mathrm{v}} 1.1\right.$ to $\mathrm{Na}_{\mathrm{v}} 1.4, \mathrm{Na}_{\mathrm{v}} 1.6$ and $\left.\mathrm{Na}_{\mathrm{v}} 1.7\right)$ or micromolar $\left(\mathrm{Na}_{\mathrm{v}} 1.5, \mathrm{Na}_{\mathrm{v}} 1.8\right.$ and $\left.\mathrm{Na}_{\mathrm{v}} 1.1\right)$ concentrations of the toxin $(4,9,12,15)$. VGSC $\beta$ are also members of the immunoglobulin superfamily of cell adhesion molecules (CAMs), and responsible for regulating channel gating (16). Four subunits of VGSC $\beta$ ( $\beta 1-\beta 4$ encoded by the genes $S C N 1 B$ to $S C N 4 B$ ) have been identified in mammals; $\beta 1, \beta 1 \mathrm{~A} / \mathrm{B}$, and $\beta 3$ are noncovalently bound to the $\alpha$ subunit, while $\beta 2$ and $\beta 4$ are linked by disulfide bonds. VGSC $\beta$ are multifunctional molecules; they boost channel kinetics, transfer voltage-dependence and expand channel expression in the cell membrane (17). These subunits also promote cell adhesion in vitro, both in the presence and absence of the $\alpha$ subunit (7). Thus they are expressed in non-excitable cells such as glia, human endothelial cells and T-lymphocytes $(10,11)$. In addition, they have been found to be overexpressed in various forms of tumors, promoting adhesion, galvanotaxis, motility and invasion, and are therefore associated with poor clinical prognosis $(9,11,18-21)$. For example, in 
prostate cancer cells, enhanced expression of VGSC $\alpha$ subunit was observed in the highly metastatic cell line MAT-LyLu/ PC-3 compared with the poorly metastatic cell line AT-2/ LNCaP (18), and tetrodotoxin treatment resulted in significant inhibition of PC3 cell invasion in vitro (20).

In breast cancer, the $\alpha$ subunit gene $(S C N 5 A)$ and $\mathrm{nNa}_{\mathrm{v}} 1.5$ protein were found to be upregulated in the highly metastatic de novo resistant MDA-MB-231 cells, in contrast to the weakly metastatic MCF-7 (3,22), and are involved in the enhancement of extracellular matrix (ECM) degradation (23), in part through activation of acidic cysteine cathepsins B and S (24).

We have established several endocrine-resistant breast cancer cell lines by shRNA-mediated silencing of ER. These have all undergone EMT, and acquired enhanced proliferative and invasive capacity towards various serum components, insulin-like growth factor-1 and epidermal growth factor (EGF) (25-27). Since VGSC expression/activity was shown to be enhanced in highly metastatic cancer cells, we were interested to test if this channel shows enhanced expression level and activity in our acquired form of endocrine-resistant breast cancer cells (pII), and if their invasive behavior is correlated with blockade of VGSC activity. In the present study, we examined the involvment of VGSCs in these cells, with respect to functions related to tumor progression, either by inhibiting channel activity with pharmacological agents (phenytoin and tetrodotoxin) or through siRNA-mediated reduction of $\mathrm{Na}_{\mathrm{v}} 1.5$ channels. We show for the first time a pro-invasive effect of VGSCs in breast cancer cells with acquired endocrine resistance, modulated in part through enhancement of proteases (cathepsin E and kallikrein 10) and MMP (such as MMP-7) activity.

\section{Materials and methods}

Cell lines. MCF-7 breast cancer cells were obtained from the American Type Culture Collection (VA, USA). pII cell line (ER silenced) was established in our laboratory by transfection of MCF-7 with ER directed shRNA plasmid as described previously $(25,27)$. For routine culture, all cell lines were maintained as monolayers in advanced Dulbecco's minimum essential medium (DMEM) containing phenol red and supplemented with $5 \%$ fetal bovine serum (FBS), $600 \mu \mathrm{g} / \mathrm{ml}$ L-glutamine, $100 \mathrm{U} / \mathrm{ml}$ penicillin, $100 \mu \mathrm{g} / \mathrm{ml}$ streptomycin and $6 \mathrm{ml} / 500$ 100X non-essential amino acids (all from Invitrogen, CA, USA), and grown at $37^{\circ} \mathrm{C}$ in an incubator gassed with an atmosphere of $5 \% \mathrm{CO}_{2}$ and maintained at $95 \%$ humidity.

Drugs, reagents and antibodies. 5,5-Diphenylhydantoin sodium salt (PHT; Sigma, USA) was prepared by dissolution in $\mathrm{NaOH}$ and stored at $-20^{\circ} \mathrm{C}$. Tetrodotoxin (TTX; Tocris, UK) was prepared by dissolution in physiological saline solution at $\mathrm{pH} 7.4$, and stored at $-80^{\circ} \mathrm{C}$. Stock solutions $(10 \mathrm{mM})$ were diluted with PBS to give final concentrations of $100 \mathrm{nM}, 1$, 10,50 and $100 \mu \mathrm{M}$. EGF powder (Sigma) was re-suspended in $0.1 \% \mathrm{BSA}$ at $0.1 \mathrm{mg} / \mathrm{ml}$, and stored in aliquots at $-20^{\circ} \mathrm{C}$. This stock solution was freshly diluted with sterile PBS to give final concentrations of 10, 50 and $100 \mathrm{ng} / \mathrm{ml}$. Phallotoxin and goat anti-rabbit IgG were obtained from Alexa. Anti-Na 1.5 antibody (ab56240) was obtained from Abcam, UK. P-ERK1/2, P-Akt, actin, and anti-HRP-conjugated secondary antibodies were obtained from Cell Signaling, USA.
Electrophysiology. Membrane currents were recorded from cells grown on glass coverslips using the whole-cell patch clamp technique, as described previously $(3,28)$. A Multiclamp 700B amplifier was used to make recordings in voltage clamp mode, compensating for series resistance by $40-60 \%$. A Digidata 1440A interface (Molecular Devices) was used to digitize currents, which were low-pass filtered at $10 \mathrm{kHz}$, sampled at $50 \mathrm{kHz}$ and then analyzed using pClamp 10.4 software. Linear leak currents were subtracted using a P/6 protocol (29).

MTT assay. Approximately $10^{4}$ cells were seeded into triplicate wells of 12-well plates and allowed to attach overnight. Either vehicle only (control) or VGSC inhibitors PHT or TTX (100 nM-100 $\mu \mathrm{M})$ were then added to the cells. Growth was assessed after 4 days of incubation. Briefly, $1 \mathrm{ml}$ of MTT [3-(4,5-dimethylthiazolyl-2)-2,5-diphenyltetrazolium bromide] reagent (Promega, USA) $(0.5 \mathrm{mg} / \mathrm{ml})$ was added to each well and plates incubated at $37^{\circ} \mathrm{C}$ for $30 \mathrm{~min}$ followed by the addition of $1 \mathrm{ml}$ acidic isopropanol and vigorous re-suspension of the converted blue dye. Absorbance of the suspension was measured at $595 \mathrm{~nm}$ with background subtraction at $650 \mathrm{~nm}$.

Cell motility wound healing assay. pII cells were cultured in 12 -well plates to $80-90 \%$ confluency. A scratch was created in the cell monolayer using a sterile p100 yellow pipette tip and an image of the scratched area was captured immediately $(0 \mathrm{~h})$. The media was then replaced with vehicle (control), phenytoin, or TTX at concentrations of $100 \mathrm{nM}, 1,10,50$ and $100 \mu \mathrm{M}$ diluted in DMEM. Cells were cultured at $37^{\circ} \mathrm{C} / 5 \% \mathrm{CO}_{2}$. After $24 \mathrm{~h}$, an image was captured of the same scratched area. The width of the scratch at $24 \mathrm{~h}$ was calculated as a percentage of the width at $0 \mathrm{~h}$; a minimum of 3 areas along the scratch were measured.

Agarose invasion assay. Ultra-pure agarose (Invitrogen) was melted in PBS, supplemented with DMEM containing $5 \% \mathrm{FBS}$, and allowed to solidify in individual wells of 6-well dishes at room temperature. Once set, cells $\left(4 \times 10^{4}\right)$ that had been exposed to various concentrations of PHT or TTX, or vehicle (control), were loaded into wells in the agarose formed as previously described (26). Plates were incubated at $37^{\circ} \mathrm{C}$ in $5 \% \mathrm{CO}_{2}$ humidified atmosphere. After $24 \mathrm{~h}$, cells that had penetrated into the agarose were manually counted by visual microscopic examination. Random cell invasion was determined as the total number of cells which moved in both lateral directions out of the well. In another experimental setup, cells were treated with EGF $(10 \mathrm{ng} / \mathrm{ml})$ in the presence or absence of various concentrations of PHT or TTX and invasion determined. In this latter case, the agarose was mixed with insulin transferrin selenium (ITS) instead of 5\% FBS since serum itself has invasive stimulatory components.

Cultrex BME cell invasion assay. pII cell invasion was also assessed by the Cultrex ${ }^{\circledR}$ 24-well BME cell invasion assay obtained from Trevigen (USA) according to the manufacturer's instructions. In brief, the invasion chamber was coated with $100 \mu \mathrm{l}$ of $1 \mathrm{X}$ basement membrane extract (BME) solution and incubated overnight at $37^{\circ} \mathrm{C}$. pII cells serum-starved overnight at $37^{\circ} \mathrm{C} / 5 \% \mathrm{CO}_{2}$, were re-suspended at $10^{6}$ cells $/ \mathrm{ml}$ in 
DMEM (control) or DMEM containing various doses of PHT $(1,10,50$ and $100 \mu \mathrm{M})$, and $100 \mu \mathrm{l}$ of suspension was loaded into the upper chamber. The lower chamber was loaded with $500 \mu 1$ DMEM supplemented with $10 \%$ FBS, as a chemoattractant. Cells were incubated at $37^{\circ} \mathrm{C}, 5 \% \mathrm{CO}_{2}$ and allowed to migrate from the top chamber to the bottom. After $48 \mathrm{~h}$, liquid from both top and bottom chambers was removed by aspiration and chambers gently washed with $1 \mathrm{X}$ cell wash buffer, provided by the supplier. Calcein-AM/cell dissociation solution complex was added to the bottom chamber and left for $1 \mathrm{~h}$ at $37^{\circ} \mathrm{C} / 5 \% \mathrm{CO}_{2}$. Cells internalize Calcein-AM and intracellular esterases cleave acetomethylester (AM) moiety generating fluorescent free calcein. Invading cells were determined by recording the fluorescence emission using a microplate reader with a filter set of excitation/emission $=$ 485/535 nm (Cultrex, 2008).

Confocal microscopy. MCF-7 and pII cells grown overnight at $37^{\circ} \mathrm{C}, 5 \% \mathrm{CO}_{2}$ in 8 -well glass chambered slides (Lab-Tek, USA) were either left untreated or exposed for $30 \mathrm{~min}$ to EGF $(50 \mathrm{ng} / \mathrm{ml})$ then fixed with $3.7 \%$ paraformaldehyde and stained with phallotoxin (green fluorescence) to visualize F-actin, $\mathrm{Na}_{\mathrm{v}} 1.5$ antibody (red fluorescence), and DAPI (blue fluorescence) to visualize the nuclei, and examined by confocal microscopy using a Carl Zeiss LSM 700 microscope.

Western blotting. pII cells were cultured in 6-well plates to $80 \%$ confluence and then serum-starved overnight before addition of either vehicle or EGF $(50 \mathrm{ng} / \mathrm{ml})$. After $30-\mathrm{min}$ exposure cells were harvested by scraping into $300 \mu \mathrm{l}$ of lysis buffer containing $50 \mathrm{mM}$ HEPES, $50 \mathrm{mM} \mathrm{NaCl}, 5 \mathrm{mM}$ EDTA $1 \%$ Triton X-100, $100 \mu \mathrm{g} / \mathrm{ml} \mathrm{PMSF}, 10 \mu \mathrm{g} / \mathrm{ml}$ aprotinin, and $10 \mu \mathrm{g} / \mathrm{ml}$ leupeptin. Protein was determined by the standard Bradford assay and $6 \mu \mathrm{g}$ were mixed with an equal volume of 2X SDS and heated at $90^{\circ} \mathrm{C}$ for $10 \mathrm{~min}$. Lysates were loaded onto a $10 \%$ SDS-polyacrylamide gel and electrophoresed at $150 \mathrm{~V}$ for $1 \mathrm{~h}$. Proteins were transferred to a nitrocellulose membrane and blocked with $2 \%$ BSA for $1 \mathrm{~h}$ before being incubated overnight at $4{ }^{\circ} \mathrm{C}$ with either total or pAkt antibody (1/600 dilution), pERK1/2 antibody (1/1,000 dilution), $\mathrm{Na}_{\mathrm{v}} 1.5$ antibody (1/100 dilution), or actin antibody (1/1,000 dilution) prepared in $2 \%$ BSA. The membrane was washed and incubated with anti-HRP-conjugated secondary antibody (1/500 dilution) for $1 \mathrm{~h}$, developed with Super Signal ECL and visualized with Kodak X-ray film.

Matrix metalloproteinase activity. The general activity of MMPs was determined using a kit from Abcam (cat no. ab112146) according to the manufacturer's protocol. pII cells were seeded into 6-well plates and allowed to grow to $80 \%$ confluence. Cells were serum starved overnight, and then either left untreated or exposed to $100 \mu \mathrm{M}$ phenytoin for $1 \mathrm{~h}$ followed by EGF stimulation $(100 \mathrm{ng} / \mathrm{ml})$ for $30 \mathrm{~min}$. Then, $25 \mu \mathrm{l}$ of the media was removed and added to $25 \mu \mathrm{l}$ of $2 \mathrm{mM}$ APMA working solution and incubated for $15 \mathrm{~min}$ at $25^{\circ} \mathrm{C}$, followed by addition of $50 \mu \mathrm{l}$ of green substrate solution. MMP activity was measured at 10 -min intervals for $1 \mathrm{~h}$, at $37^{\circ} \mathrm{C}$ by recording fluorescence emission using a microplate reader with a filter set of excitation/emission $=485 / 535 \mathrm{~nm}$.
Proteome profiler analysis. The relative change in 35 human proteases was detected using Proteome Profiler ${ }^{\mathrm{TM}}$ human protease array kit (cat no. ARY021B, R\&D Systems, Inc., Minneapolis, MN, USA) following the manufacturer's protocol. Briefly, pII cells were cultured in 6-well plates until reaching 80-90\% confluency, then serum-starved overnight, and either left untreated (UT, control) or exposed to $50 \mu \mathrm{M}$ phenytoin for $1 \mathrm{~h}$ followed by EGF stimulation $(100 \mathrm{ng} / \mathrm{ml})$ for $30 \mathrm{~min}$. Cell lysate was harvested by scraping into $300 \mu \mathrm{l}$ of lysis buffer containing $50 \mathrm{mM}$ HEPES, $50 \mathrm{mM} \mathrm{NaCl}, 5 \mathrm{mM}$ EDTA $1 \%$ Triton X-100, $100 \mu \mathrm{g} / \mathrm{ml}$ PMSF, $10 \mu \mathrm{g} / \mathrm{ml}$ aprotinin, and $10 \mu \mathrm{g} / \mathrm{ml}$ leupeptin. Protein was determined by the standard Bradford assay. Nitrocellulose membranes with duplicate spots of selected capture antibodies were incubated in $2 \mathrm{ml}$ of array buffer 6 (works as blocking buffer) in 4-well multidishes on a rocking platform for $1 \mathrm{~h}$. For each membrane, protein samples $(200 \mu \mathrm{g})$ were incubated at room temperature with $15 \mu \mathrm{l}$ of protease detection cocktail for $1 \mathrm{~h}$, before adding onto the membrane, and incubated overnight at $4^{\circ} \mathrm{C}$. The membranes were then washed with $1 \mathrm{X}$ wash buffer and incubated with streptavidin HRP for 30 min. Following another wash, the membranes were incubated with chemi-reagent mix and exposed for 10-20 min. Spot intensity was quantified using a densitometer and the average of duplicate spots on the membrane was normalized with the average negative control spots according to the manufacturer's protocol.

siRNA transfection. pII cells were plated in 12-well plates in complete DMEM and incubated for $18 \mathrm{~h}$ at $37^{\circ} \mathrm{C}, 5 \%$ $\mathrm{CO}_{2}$. Transfection was performed using $25 \mathrm{pmol}$ of $\mathrm{Na}^{+} \mathrm{CP}$ type V $\alpha$ siRNA (h) obtained from Santa Cruz Biotechnology (cat no. sc-42640). Solution A was prepared following the manufacturer's protocol by diluting $1 \mu 1$ Stemfect RNA transfection reagent (Stemgent, cat no. 00-0069) into $24 \mu \mathrm{l}$ buffer. Solution B was made by diluting $2.5 \mu \mathrm{l}$ of siRNA transfection reagent into $22.5 \mu \mathrm{l}$ of buffer. Solutions A and B were then mixed, incubated for $15 \mathrm{~min}$, and added dropwise to the cells. After 48-72 h cells were harvested and RNA extracted for determination of SCN5A expression by SYBR-Green real-time quantitative PCR as described below.

RNA extraction. RNA was extracted from transfected pII cells and purified using the RNeasy kit (Qiagen, USA) following the manufacturer's protocol. The concentration and yield of RNA was determined spectroscopically using the Nano-Drop (Pharmacia) and integrity checked by agarose gel electrophoresis.

Quantitative real-time PCR.RNA was converted to cDNA using a High-Capacity cDNA Reverse Transcription kit from Applied Biosystems. Quantitative PCR was performed in the ABI 7500 FAST thermocycler in a reaction volume of $20 \mu \mathrm{l}$ using the SYBER green master mix from Invitrogen). Primers for $S C N 5 A$ gene (forward primer 5'-CACGCGTTCACTTTCCTTC-3', reverse primer 5'-CATCAGCCAGCTTCTTCACA-3'; 208-bp product) and $\beta$-actin were synthesized in the HSC Research Core Facility, Kuwait University.

Statistical analysis. Means of various groups were compared using the Sudent's t-test. Differences were considered significant at $\mathrm{p} \leq 0.05$. 

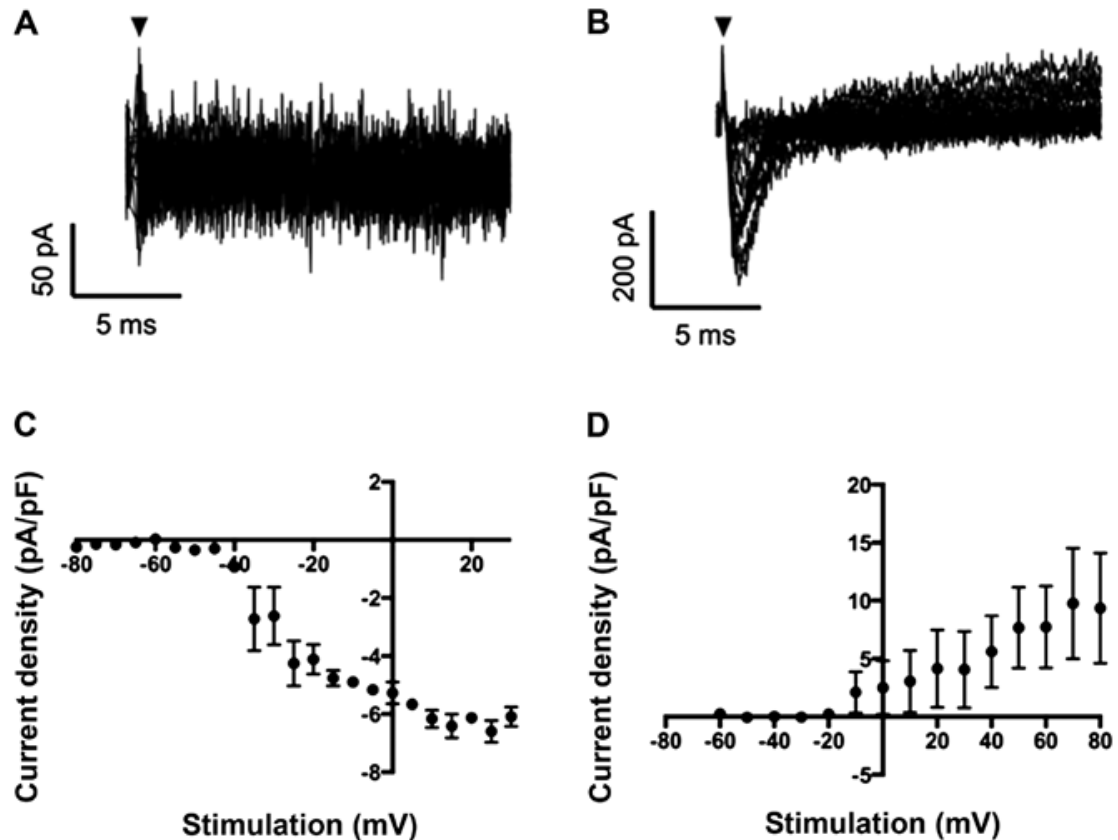

Figure 1. VGSC currents in MCF-7 and pII cells. (A) Representative trace showing that there was no obvious inward current in MCF-7 cells. (B) pII cell exhibiting fast inward VGSC current. (C) Inward and (D) outward current-voltage relationship of pII cells. Cells were held at $-120 \mathrm{mV}$ for $250 \mathrm{~ms}$ before depolarization to voltages ranging from -80 to $+30 \mathrm{mV}$ in $5 \mathrm{mV}$ increments for $50 \mathrm{~ms}$.

A

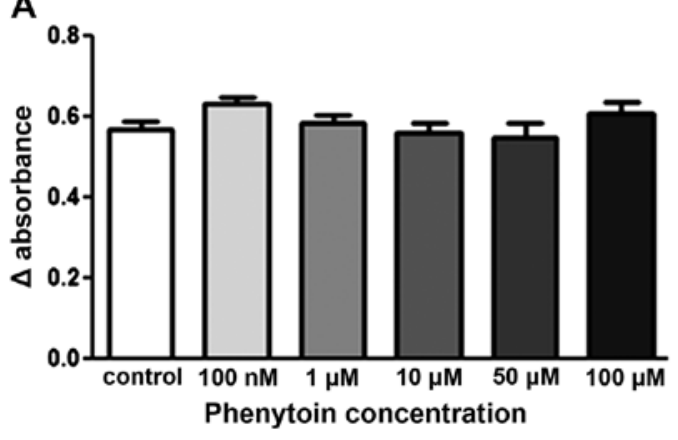

B

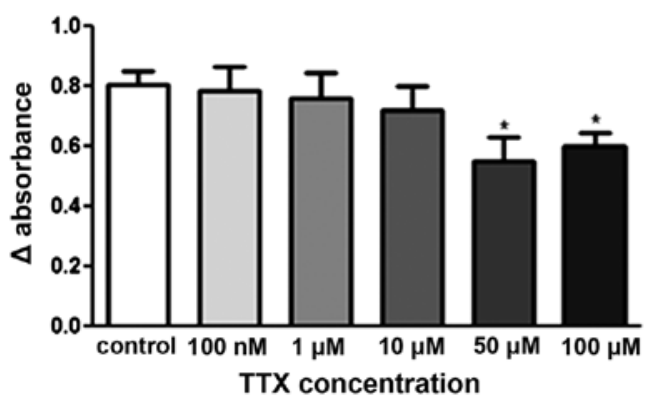

C

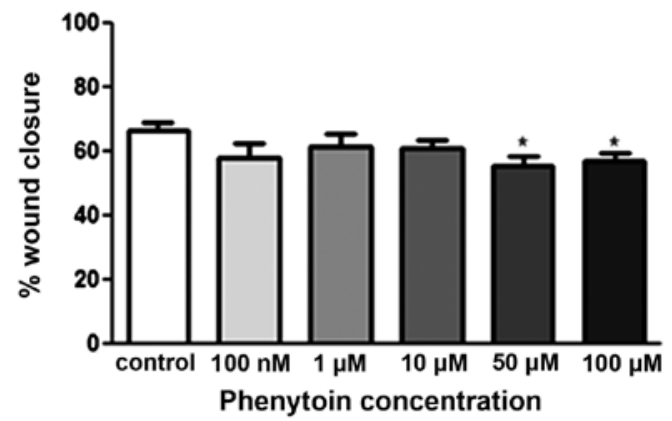

D

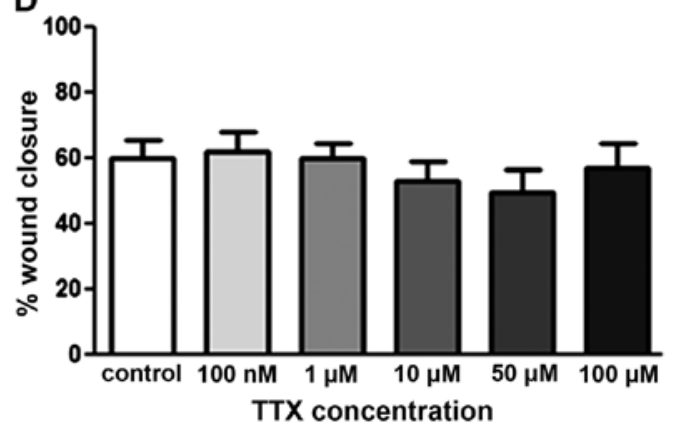

Figure 2. Effect of PHT and TTX on proliferation and motility of pII cells. Cells grown in microtitre plates were either left untreated (control, open bars) or exposed to PHT/TTX at the concentrations indicated. Growth was assessed by MTT assay after 4 days of incubation (A and B). Motility was determined by the wound healing assay after $24 \mathrm{~h}$ of incubation (C and D). Histobars represent the mean \pm SEM of 4-14 independent determinations, ${ }^{*}$ Significant difference from control with $\mathrm{p} \leq 0.05$.

\section{Results}

VGSC current in pII and MCF-7 cells. Whole-cell patch clamp recording revealed that VGSC currents were absent in MCF-7 cells ( $n=8$ recordings), consistent with previous reports (Fig. 1A) (22). Interestingly, however, ER silencing in pII cells resulted in the upregulation of a fast inward $\mathrm{Na}^{+}$current in 2 of 5 cells recorded (Fig. 1B-D).

Effect of phenytoin and TTX on pII cell proliferation and motility. The effect of various doses $(100 \mathrm{nM}-100 \mu \mathrm{M})$ of PHT and TTX on pII cell proliferation was assessed using the MTT 

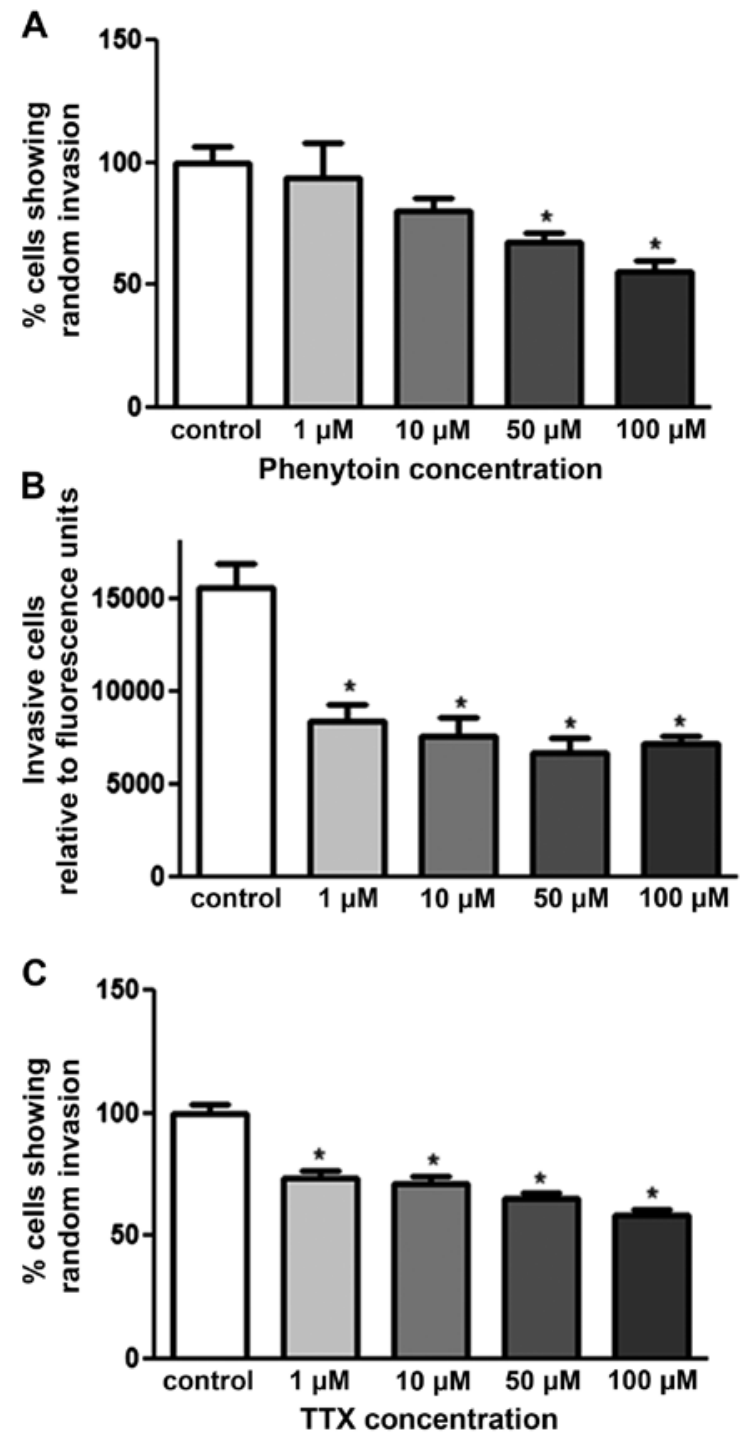

Figure 3. Effect of PHT and TTX on invasion of pII cells towards serum components. Cells were either left untreated (control, open bars) or exposed to various doses of PHT/TTX. The total number of pII cells penetrating into the agarose layer were manually counted as described in Materials and methods [control set as 100\%; (A and C)]. (B) The effect of phenytoin on penetration of cells through a basement membrane extract (BME) using the Matrigel assay towards serum components. The $\mathrm{y}$-axis shows arbitrary fluorescence units indicating uptake of Calcein into penetrating cells as described in Materials and methods. Histobars represent the mean \pm SEM of 3-18 independent determinations, "Significant difference from control with $\mathrm{p} \leq 0.05$.

assay. As shown in Fig. 2A, phenytoin had no effect, while TTX exhibited a small inhibitory effect (25-30\%) when used at the higher concentrations (50-100 $\mu \mathrm{M}$; Fig. 2B). On the other hand, TTX had no effect on cell motility whereas phenytoin had a small (8-10\%) inhibitory effect at 50-100 $\mu \mathrm{M}$ (Fig. 2C and D).

Effect of PHT and TTX on random invasion of pII cells towards serum components. The agarose invasion assay was used to determine the effect of VGSC inhibitors on pII invasion towards serum components. As shown in Fig. 3A and $\mathrm{C}$, both drugs exhibited dose-dependent inhibition; PHT exerted its effect at 50 and $100 \mu \mathrm{M}$ with 40 and $50 \%$ inhibition respectively. TTX exhibited its effect from a lower concentration $(1 \mu \mathrm{M})$ with $25 \%$ inhibition. Matrigel invasion assay was used to confirm the anti-invasive property of PHT. Fig. 3B shows a significant inhibitory effect of PHT at all doses used (1-100 $\mu \mathrm{M})$ with 50\% inhibition.

Distribution and expression profile of VGSCs in endocrine sensitive and resistant breast cancer cell lines. Immunofluorescence indicated a similar diffuse cytoplasmic as well as perinuclear distribution of $\mathrm{Na}_{\mathrm{v}} 1.5$ in both MCF-7 and pII cells (Fig. 4A and B). Measurement of total protein by western blotting showed enhanced expression upon EGF stimulation (at $50 \mathrm{ng} / \mathrm{ml}$ ) in pII cells; the cellular distribution of $\mathrm{Na}_{\mathrm{v}} 1.5$ remained unchanged (Fig. 4C-E).

Effect of PHT and TTX on invasion of pII cells towards $E G F$. Fig. 5A and B shows a significant increase in the invasive capacity of pII cells towards the well containing EGF compared to vehicle (PBS, hatched bars); this was associated with elevated ERK1/2 phosphorylation and total MMP activity (Fig. 5C and D, second line; and E, open circles). Both drugs (PHT and TTX) showed similar dose-dependent inhibition of the EGF-induced invasion. As shown in Fig. 5B and $\mathrm{C}$ (line 6), the anti-invasive property of VGSCs was in part through reducing EGF-induced ERK1/2 (but not Akt) phosphorylation as well as reduction of EGF-induced MMP activity (Fig. 5E). In addition, by using the human protease profiler kit, we observed that EGF stimulation significantly enhanced the levels of cathepsin E, kallikrein-10 and MMP-7 (Fig. 5F) relative to controls. This effect was significantly inhibited by pre-treatment with phenytoin.

$N a_{v} 1.5$ knockdown by siRNA transfection. Fig. 6A shows a significant decrease in expression of SCN5A mRNA (80\%) at $48 \mathrm{~h}$ post-transfection with targeting siRNA. Knockdown of $\mathrm{Na}_{\mathrm{v}} 1.5$ protein was confirmed by immunofluorescence with anti-VGSC antisera. Whereas there was clear cytoplasmic as well as perinuclear staining in cells transfected with a scrambled sequence the specific siRNA transfected cells showed almost no signal (Fig. 6B and C). Cytoskeletal staining with phallotoxin was the same in both.

Effect of SCN5A knockdown on pII cell motility and invasion. As shown in Fig. 7A SCN5A mRNA knockdown did not affect pII cell motility compared to control, but significantly inhibited invasion (50\%) towards serum components and EGF (Fig. 7B and C).

\section{Discussion}

Although VGSCs are mainly expressed in the plasma membrane of neuronal cells (28), these channel proteins could have roles aside from regulating membrane potential. We showed that $\mathrm{Na}_{\mathrm{v}} 1.5$ is expressed in the cytoplasmic and perinuclear region, as well as in the lamellipodia, of highly invasive breast cancer cells, suggesting a role in cell migration and invasion $(3,5-7,29)$. We have previously documented that the expression of $S C N 5 A$ gene (encoding $\mathrm{Na}_{\mathrm{v}} 1.5$ protein) was significantly increased (by 4-fold) in the highly invasive ER silenced pII cells compared to the ER ${ }^{+} \mathrm{MCF}-7$ cells which have little invasive capacity (27). In view of these findings, we 


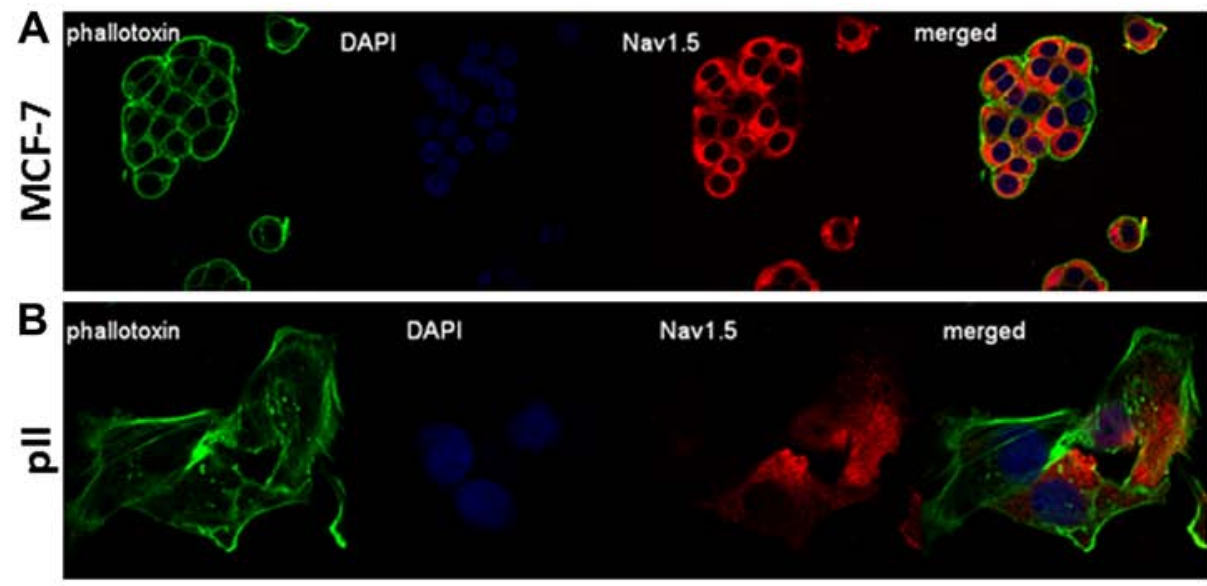

C

$10 \mathrm{ng} / \mathrm{ml} \mathrm{EGF} 50 \mathrm{ng} / \mathrm{ml} \mathrm{EGF}$

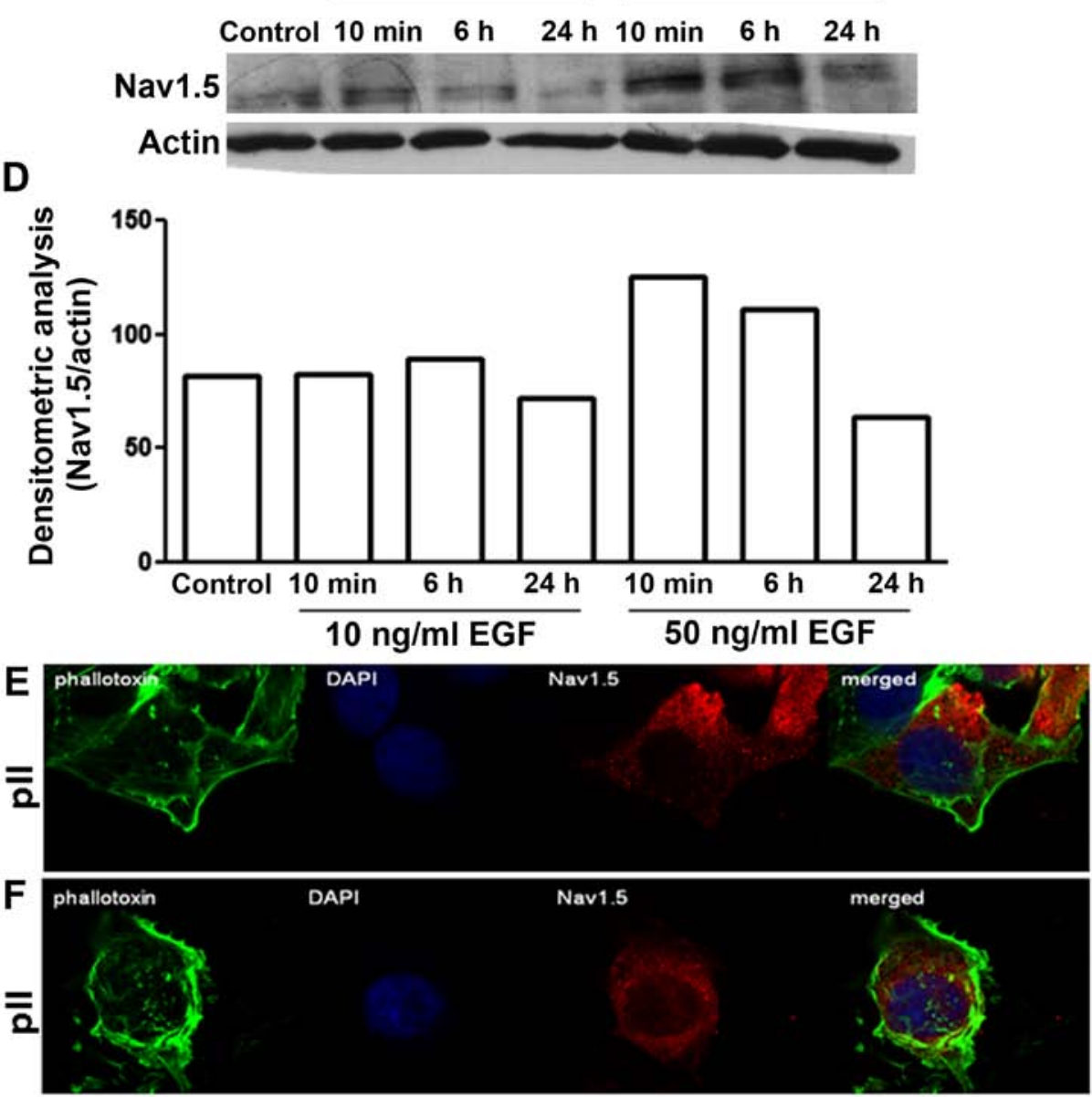

Figure 4. Distribution of VGSCs in MCF-7 and pII cells. Cells were seeded into 8 -chambered slides and allowed to grow for $48 \mathrm{~h}$ at $37^{\circ} \mathrm{C} / 5 \% \mathrm{CO}_{2}$. Cells were then fixed and stained with $\mathrm{Na}_{\mathrm{v}} 1.5$ antibody (red), phallotoxin (green) and DAPI (blue). (A) MCF-7. (B and E) pII untreated. (F) pII stimulated with EGF $10 \mathrm{ng} / \mathrm{ml}$ for $30 \mathrm{~min}$. (C) pII cells serum starved for $2 \mathrm{~h}$ and then either left untreated (control) or exposed to $10 \mathrm{or} 50 \mathrm{ng} / \mathrm{ml}$ EGF and subsequently harvested at $10 \mathrm{~min}, 6 \mathrm{~h}$ and $24 \mathrm{~h}$. Protein lysates were electrophoresed in 10\% SDS-polyacrylamide gel, blotted onto nitrocellulose membrane and probed with antisera against $\mathrm{Na}_{\mathrm{v}} 1.5$ and $\beta$-actin. (D) Densitometric analysis of the bands in the blot in (C) expressed as a ratio of Nav1.5/actin for normalisation.

investigated the expression and involvement of VGSCs in pII cells using whole-cell patch clamp recording, pharmacological inhibitors (PHT and TTX) and siRNA-mediated knockdown of $\mathrm{Na}_{\mathrm{v}} 1.5$ protein. Our observations show that VGSC currents were only detectable in pII cells, and not in MCF-7 cells, suggesting a role in modulating various functions such as cell invasion. Upregulation of the SCN5A gene in pII cells compared to MCF-7 might explain the absence of the VGSC current in latter cells. In addition, cells that have undergone EMT (due to ER loss) acquire enhanced invasive capacity and upregulate the level/activity of various growth factor receptors, signalling and adhesion molecules, as well as ion channels. VGSCs can promote cell invasion, in part through modulation of EGF-induced ERK1/2 phosphoryla- 
A

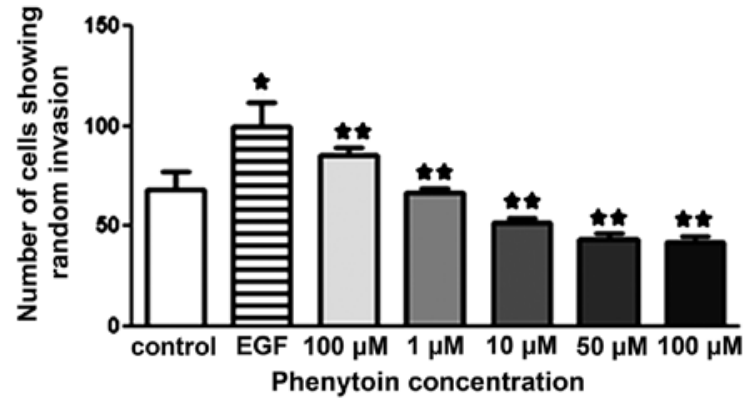

B

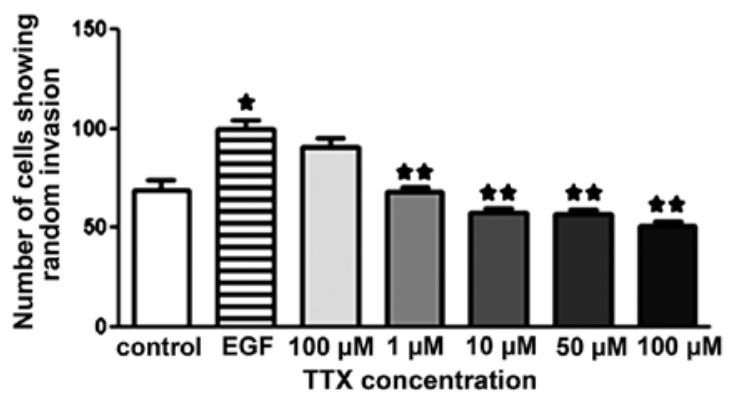

C

$50 \mathrm{nM} 100 \mathrm{nM} 1 \mu \mathrm{M} \quad 50 \mu \mathrm{M}$

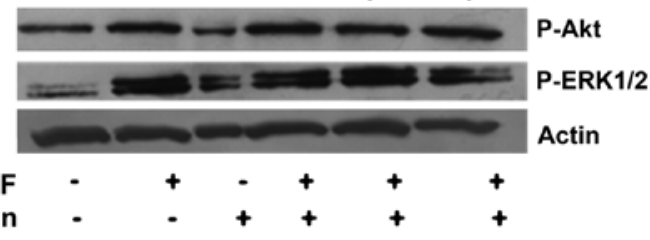

D

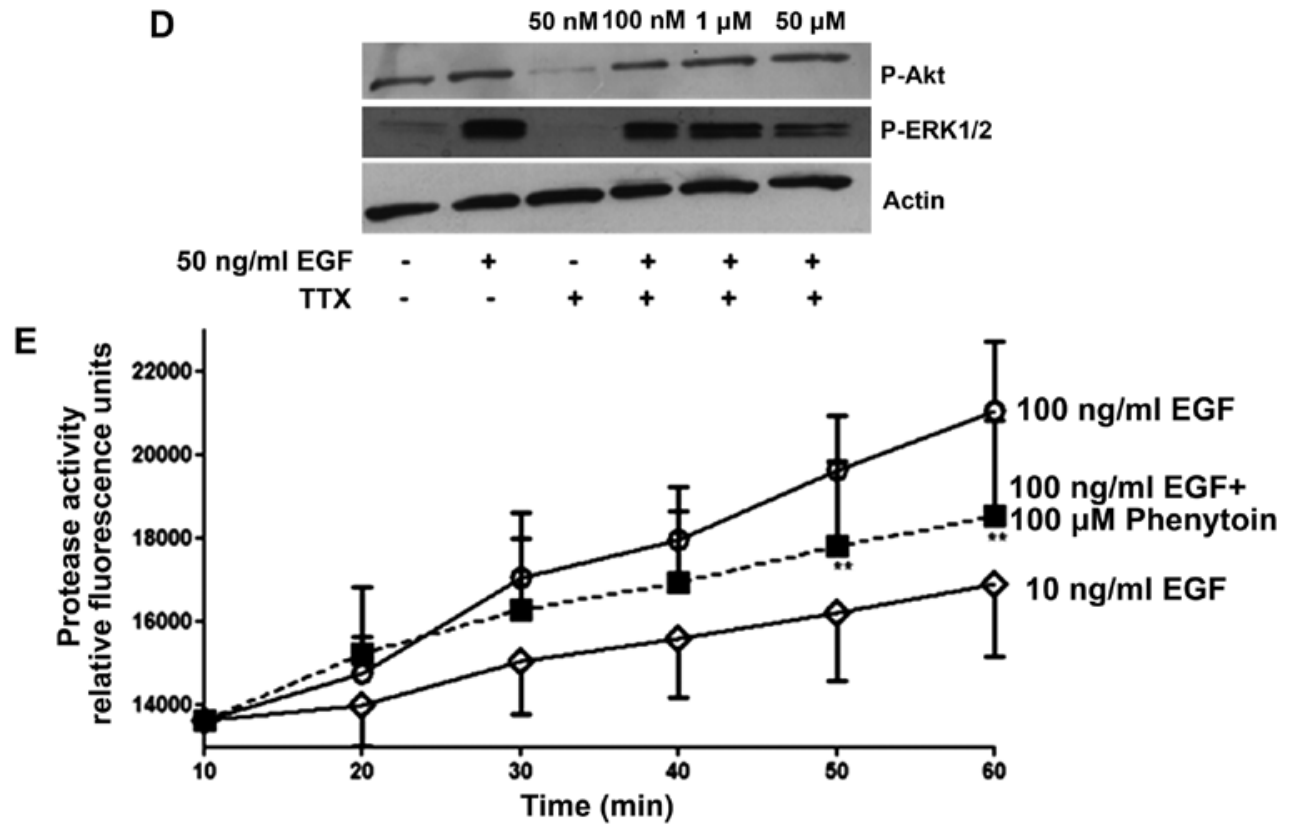

$\mathbf{F}$

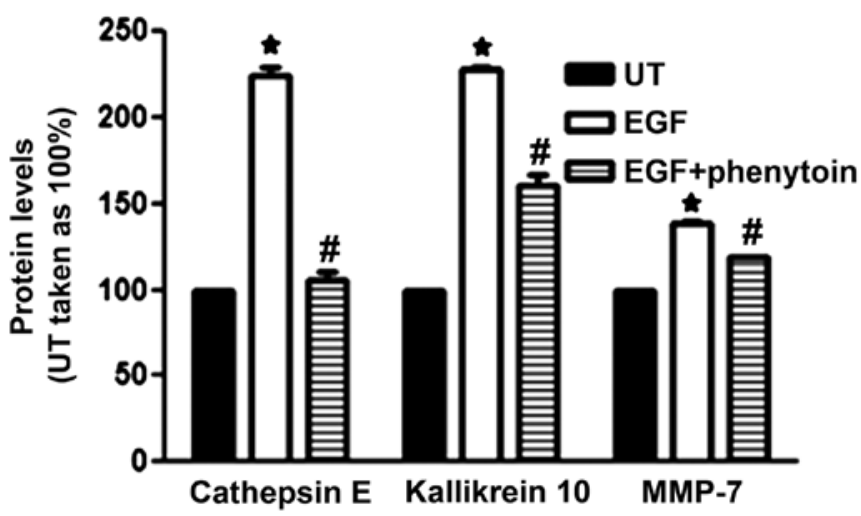

Figure 5. Effect of PHT and TTX on EGF-induced invasion, protease levels, and MMP activity. (A and B) pII cells were either left untreated (control, open bars), treated with EGF (50 ng/ml, hatched bars), or pre-treated with various doses of PHT/TTX plus EGF (solid bars). Total number of cells penetrating into the agarose layer were manually counted as described in Materials and methods. (C and D) pII cells were serum starved overnight and either left untreated or stimulated with EGF in the presence or absence of PHT/TTX. Protein lysates were electrophoresed on SDS-PAGE and proteins transferred onto nitrocellulose membrane and probed with antisera against P-ERK1/2, P-Akt, or actin. (E) pII cells were seeded into 6-well plates and grown until 90\% confluent, then serum starved overnight. Cells were then treated with EGF (10 and $100 \mathrm{ng} / \mathrm{ml})$ with or without PHT pre-treatment $(50 \mu \mathrm{M}$, for $1 \mathrm{~h})$. MMP activity was determined using a fluorogenic substrate (as described in Materials and methods). (F) Protease levels were determined in pII cells; untreated (solid bars), treated with EGF $(100 \mathrm{ng} / \mathrm{ml}$, open bars), or treated with phenytoin $(50 \mu \mathrm{M})$ followed by EGF treatment (100 $\mathrm{ng} / \mathrm{ml}$, hatched bars). Histobars represent the mean \pm SEM of 3-14 independent determinations. *Significant difference (with $\mathrm{p} \leq 0.05$ ) from control; "EGF treatment. 

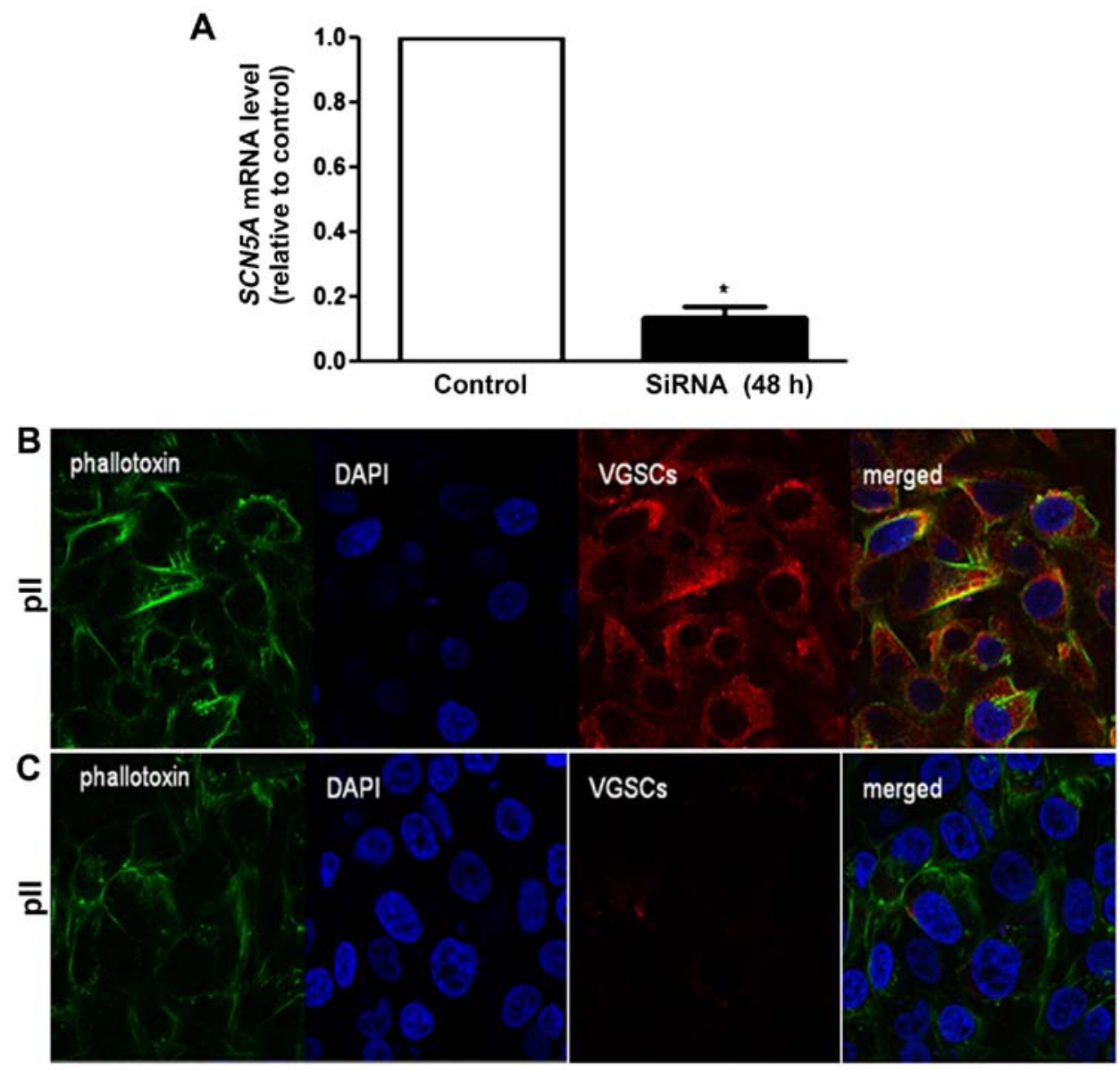

Figure 6. VGSC knockdown by siRNA transfection. (A) pII cells were seeded into 12-well plates, allowed to attach overnight and then either transfected with a scrambled sequence (open bar) or SCN5A siRNA (solid bar). RNA was extracted from the cells, converted to cDNA and PCR amplified. Ct values were converted to ratios as described in Materials and methods. Histobars represent mean \pm SEM of 3 independent determinations. *Significant difference from

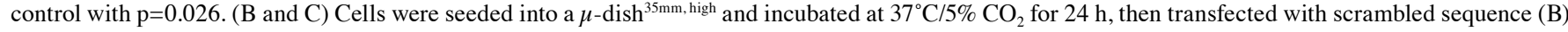
or SCN5A siRNA (C). After $48 \mathrm{~h}$, cells were fixed and stained with $\mathrm{Na}_{\mathrm{v}} 1.5$ antibody (red), phallotoxin (green) or DAPI (blue).

tion, protease levels, and MMP activity. We found the same pattern of $\mathrm{Na}_{\mathrm{v}} 1.5$ expression in MCF-7 and pII cells; this localization was not changed by EGF stimulation.

Changes in $\mathrm{Na}^{+}$fluxes in metastatic cancer cells have been shown to regulate intracellular pro-invasive signaling cascades, e.g., persistent MAP kinase signaling leading to downstream phosphorylation of ERK and other targets $(30,31)$. Persistent $\mathrm{Na}^{+}$currents may contribute to invasion via several mechanisms, including: a) allosteric regulation of the $\mathrm{Na}^{+} / \mathrm{H}^{+}$exchanger, NHE1, giving rise to extracellular acidification (23), b) reverse mode of the $\mathrm{Na}^{+} / \mathrm{Ca}^{2+}$ exchanger, $\mathrm{NCX}$, potentiating intracellular $\mathrm{Ca}^{2+}$ signaling (32), c) promotion of invadopodia formation via src kinase activity and cortactin phosphorylation (33), and d) regulation of $\beta 1$-mediated adhesion-dependent migration and invasion (21). These various mechanisms have been reviewed extensively $(34,35)$.

It has been suggested that Fyn kinase activates the fynfocal adhesion kinase (FAK)-ERK1/2 pathway, leading to neurite outgrowth (36). In MDA-MB-231 breast cancer cells, fyn kinase was shown to co-localize with the $\beta 1$ subunit of VGSC, and pharmacological, as well as siRNA-mediated fyn inhibition, resulted in inhibition of the $\beta 1$-mediated process outgrowth (which is proposed to be mediated through ERK1/2 phosphorylation) (21). In Mat-LyLu rat prostate cancer cells, EGF treatment (for $24 \mathrm{~h}$ ) significantly increased VGSC current density and cell migration. Importantly, EGF treatment in the presence of TTX (a highly selective VGSC blocker) abolished $65 \%$ of the potentiating effect of EGF suggesting that a significant portion of the EGF-induced enhancement of migration occurred via VGSC activity (37). In our study, we showed that EGF treatment significantly enhanced VGSC protein expression (Fig. 4) and siRNA-mediated knockdown of VGSC inhibited EGF-induced invasion in pII cells (Fig. 7C), which is consistent with the data obtained from the prostate cancer cells. We also observed a significant inhibition of ERK1/2 phosphorylation by phenytoin and TTX treatment (Fig. 5) consistent with an involvement in VGSC-mediated invasion of pII cells.

Phenytoin is an anti-epileptic and class $1 \mathrm{~b}$ anti-arrhythmic agent which inhibits the activity of VGSCs (38). Its binding affinity to VGSCs increases when the channels are in the inactivated state (39). Subtypes of VGSCs such as $\mathrm{Na}_{\mathrm{v}} 1.5$ do not reach a complete inactivation state and carry steady-state $\mathrm{Na}^{+}$ currents at depolarized potential $(40,41)$. Cancer cells possess a more depolarized membrane potential compared to normal epithelial or excitable cells, suggesting that some permanent 

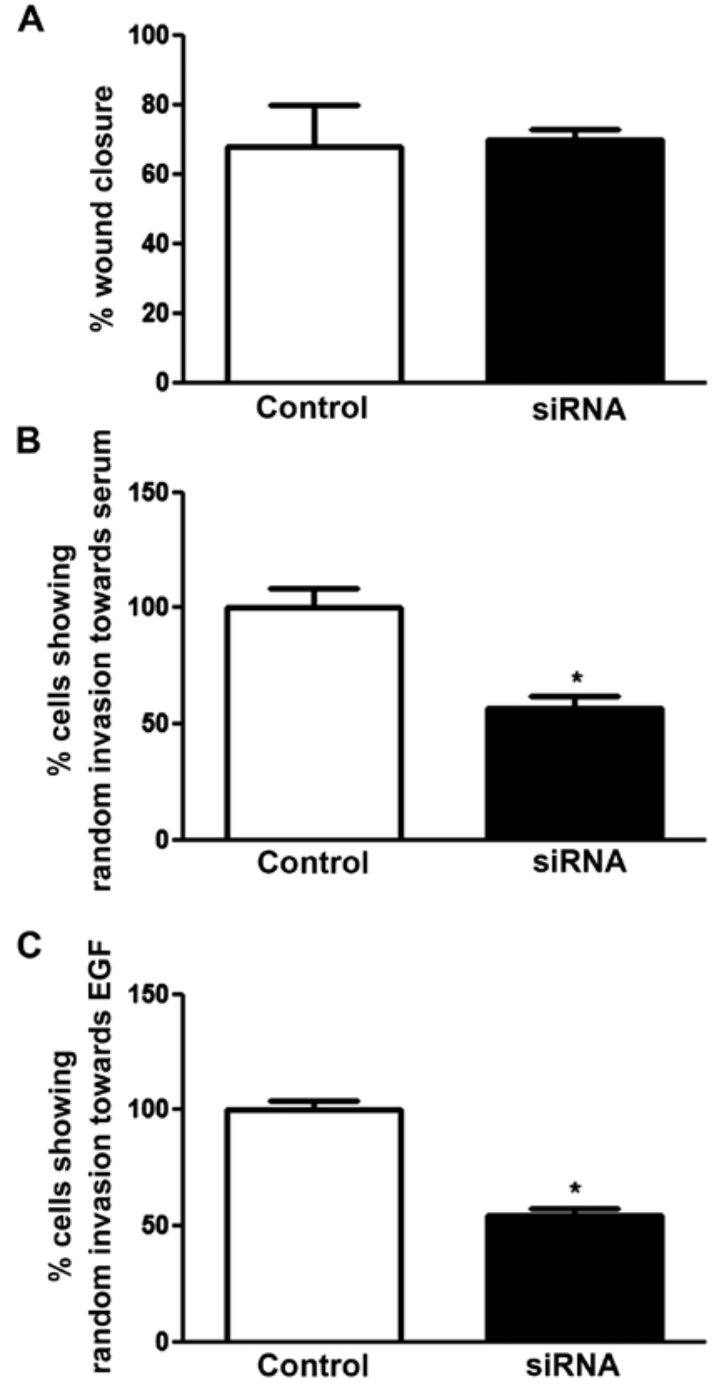

Figure 7. Effect of SCN5A siRNA knockdown on pII cell motility and invasion Cells were either transfected with scrambled sequence (control, open bars) or with SCN5A siRNA (solid bars). Motility (A), and invasion towards serum components (B) or EGF (C) was determined as described in Materials and methods. Histobars represent the mean \pm SEM of 3-6 independent determinations. "Significant difference from control, with $\mathrm{p} \leq 0.05$.

$\mathrm{Na}^{+}$current may be involved in invasion and migratory activity $(3,42)$. At concentrations $(50 \mu \mathrm{M})$ that are used in treatment of epilepsy, phenytoin significantly inhibits both persistent and transient $\mathrm{Na}^{+}$currents in the de novo resistant breast cancer cells MDA-MB-231, resulting in reduction of their invasive potential $(3,43)$. Furthermore, phenytoin significantly inhibits growth, invasion and metastasis of orthotopic MDA-MB-231 breast tumors in vivo (44). However, phenytoin had no effect on MCF-7 cell migration or invasion (they do not express $\mathrm{Na}^{+}$ currents), nor on cell proliferation of either MDA-MB-231 or MCF-7 in vitro (3). TTX, also considered a highly specific VGSC blocker, is reported to suppress metastatic behaviour in human breast, prostate and lung cancer cells in vitro. Cell proliferation was also not affected by TTX treatment, suggesting involvement specifically in cell invasion $(4,8,45)$. We observed similar effects of PTH/TTX in pII cells as potent anti-invasive agents (Fig. 3) without significantly modulating either cell proliferation or motility. A marginal decrease was seen in cell proliferation at higher doses of TTX $(50-100 \mu \mathrm{M}$; Fig. 2B), and a marginal decrease in cell motility with higher doses of phenytoin treatment (50-100 $\mu \mathrm{M}$; Fig. 1C). It should be noted that the anti-invasive property of PHT or TTX was not due to inhibiting cell proliferation since 24-48-h treatment (the time-point used for the invasion assays) did not affect cell proliferation with either drug (data not shown). Differences in effect on motility and proliferation might be due to the lack of specificity of these agents particularly at higher doses. Therefore, the siRNA-approach was used to confirm these findings in a more specific way. siRNA mediated knockdown of VGSC $\alpha$ isoforms has been reported to supress breast cancer cell invasion $(4,24,45)$, which is in aggreement with our data in pII cells (Fig. 6B and C).

In order to metastasize, cancer cells have to degrade the extracellular matrix (ECM) components, and VGSCs have been suggested to play a role in this process through $\mathrm{Na}^{+} / \mathrm{H}^{+}$ exchanger type I (NHE-1) activation. Fraser et al (22) showed that VGSCs (specifically $\mathrm{Na}_{\mathrm{v}} 1.5$ ) increase $\mathrm{Na}^{+}$influx, which in turn activates the NHE-1 present in caveolae. NHE-1 plays a role in $\mathrm{Na}^{+}$influx regulation, leading to extracellular acidification of the tumor microenvironment, resulting in activation of $\mathrm{pH}$-dependent extracellular matrix degradation by cysteine cathepsins B and S, and subsequent enhancement in cell invasion (23). Matrix metalloproteinases (MMPs) are among the proteins involved in invasion by virtue of their ability to degrade various ECM components including collagens, laminin, fibronectin, vitronectin, enactin, tenascin, elastin and proteoglycans (46). They are also thought to play a crucial role in tumor invasion, metastasis, migration and angiogenesis $(47,48)$. Pharmacological blockade of $\mathrm{Na}_{\mathrm{v}} 1.5$ channels in MDA-MB-231 cells result in a significant decrease in MMP-9 mRNA expression and cell invasion (49), which is also in agreement with our finding of increased MMP activity in the presence of EGF (Fig. 4E). We showed that the most significant inhibitory effect of phenytoin was observed on EGF-induced cathepsin E levels (Fig. 4F). Cathepsin E has been suggested as a possible marker for pancreatic tumors $(50,51)$, and interestingly, a recent study demonstrated a positive correlation between enhanced serum levels of cathepsin E and poor clinical prognosis in breast cancer patients. Mice overexpressing cathepsin E demonstrated enhanced tumor growth and metastasis through induction of the EMT process (52).

From a therapeutic viewpoint, VGSC blockade has been reported to relieve severe cancer pain in patients receiving chemotherapy (53-55). In fact, the newly FDA approved drug, Riluzole, blocks VGSC activity and inhibits metabotropic glutamine receptor, and was reported to prevent side effects related to cancer chemotherapy (56). In addition, Riluzole reduced the metabolic activity of tumors in patients with resectable stage III and IV melanoma (57). Furthermore, the use of VGSC blockers during radical prostatectomy minimized cancer recurrence and metastasis $(58,59)$. Recently, it was suggested that further investigation of the FDA-approved VGSC blockers which are already in the market (for other diseases such as epilepsy and arrhythmia, and for inducing local anaesthesia) should be tested for human metastatic diseases. In conclusion, our data suggest a promising anti-metastatic role for VGSC blockers in acquired forms of endocrine resistance in breast cancer. 


\section{Acknowledgements}

This study was supported by Kuwait University Research Sector grant YP02/13. This study was supported in part by grant SRUL02/13 to the Research Unit for Genomics, Proteomics and Cellomics Studies at the HSC, Kuwait University, and by a grant from the UK Medical Research Council (Fellowship G1000508). We would like to acknowledge Princy Mathew for technical assistance.

\section{References}

1. Yang LH, Tseng HS, Lin C, Chen LS, Chen ST, Kuo SJ and Chen DR: Survival benefit of tamoxifen in estrogen receptornegative and progesterone receptor-positive low grade breast cancer patients. J Breast Cancer 15: 288-295, 2012.

2. Al Saleh S, Sharaf LH and Luqmani YA: Signalling pathways involved in endocrine resistance in breast cancer and associations with epithelial to mesenchymal transition (Review). Int J Oncol 38: 1197-1217, 2011.

3. Yang M, Kozminski DJ, Wold LA, Modak R, Calhoun JD, Isom LL and Brackenbury WJ: Therapeutic potential for phenytoin: Targeting $\mathrm{Na}(\mathrm{v}) 1.5$ sodium channels to reduce migration and invasion in metastatic breast cancer. Breast Cancer Res Treat 134: 603-615, 2012.

4. Onkal R and Djamgoz MBA: Molecular pharmacology of voltage-gated sodium channel expression in metastatic disease: Clinical potential of neonatal Nav1.5 in breast cancer. Eur J Pharmacol 625: 206-219, 2009.

5. Chioni A-M, Brackenbury WJ, Calhoun JD, Isom LL and Djamgoz MB: A novel adhesion molecule in human breast cancer cells: Voltage-gated $\mathrm{Na}^{+}$channel beta1 subunit. Int J Biochem Cell Biol 41: 1216-1227, 2009.

6. Brackenbury WJ, Djamgoz MBA and Isom LL: An emerging role for voltage-gated $\mathrm{Na}^{+}$channels in cellular migration: Regulation of central nervous system development and potentiation of invasive cancers. Neuroscientist 14: 571-583, 2008.

7. Brackenbury WJ, Davis TH, Chen C, Slat EA, Detrow MJ, Dickendesher TL, Ranscht B and Isom LL: Voltage-gated $\mathrm{Na}^{+}$ channel beta1 subunit-mediated neurite outgrowth requires Fyn kinase and contributes to postnatal CNS development in vivo. J Neurosci 28: 3246-3256, 2008.

8. Gillet L, Roger S, Bougnoux P, Le Guennec J-Y and Besson P: Beneficial effects of omega-3 long-chain fatty acids in breast cancer and cardiovascular diseases: Voltage-gated sodium channels as a common feature? Biochimie 93: 4-6, 2011.

9. Hernández-Plata E: Role of the voltage-gated sodium channels in the metastatic capacity of cancer cells. Rev Invest Clin 64: 567-575, 2012 (In Spanish).

10. Brackenbury WJ and Isom LL: Voltage-gated Na channels: Potential for $\beta$ subunits as therapeutic targets. Expert Opin Ther Targets 12: 1191-1203, 2008.

11. Roger S, Potier M, Vandier C, Besson P and Le Guennec J-Y: Voltage-gated sodium channels: New targets in cancer therapy? Curr Pharm Des 12: 3681-3695, 2006.

12. Potier M, Joulin V, Roger S, Besson P, Jourdan ML, Leguennec JY, Bougnoux P and Vandier C: Identification of SK3 channel as a new mediator of breast cancer cell migration. Mol Cancer Ther 5: 2946-2953, 2006

13. Goldin AL: Resurgence of sodium channel research. Annu Rev Physiol 63: 871-894, 2001.

14. Goldin AL, Barchi RL, Caldwell JH, Hofmann F, Howe JR, Hunter JC, Kallen RG, Mandel G, Meisler MH, Netter YB, et al: Nomenclature of voltage-gated sodium channels. Neuron 28: 365-368, 2000

15. Hernández-Plata E, Ortiz CS, Marquina-Castillo B, MedinaMartinez I, Alfaro A, Berumen J, Rivera M and Gomora JC: Overexpression of $\mathrm{NaV} 1.6$ channels is associated with the invasion capacity of human cervical cancer. Int J Cancer 130: 2013-2023, 2012.

16. Yildirim S, Altun S, Gumushan H, Patel A and Djamgoz MBA: Voltage-gated sodium channel activity promotes prostate cancer metastasis in vivo. Cancer Lett 323: 58-61, 2012.

17. Isom LL and Catterall WA: $\mathrm{Na}^{+}$channel subunits and Ig domains. Nature 383: 307-308, 1996.
18. Diss JK, Archer SN, Hirano J, Fraser SP and Djamgoz MB: Expression profiles of voltage-gated $\mathrm{Na}(+)$ channel alpha-subunit genes in rat and human prostate cancer cell lines. Prostate 48: $165-178,2001$.

19. Djamgoz MB and Onkal R: Persistent current blockers of voltagegated sodium channels: A clinical opportunity for controlling metastatic disease. Recent Patents Anticancer Drug Discov 8: 66-84, 2013.

20. Laniado ME, Lalani EN, Fraser SP, Grimes JA, Bhangal G, Djamgoz MB and Abel PD: Expression and functional analysis of voltage-activated $\mathrm{Na}^{+}$channels in human prostate cancer cell lines and their contribution to invasion in vitro. Am J Pathol 150: 1213-1221, 1997.

21. Nelson M, Millican-Slater R, Forrest LC and Brackenbury WJ: The sodium channel $\beta 1$ subunit mediates outgrowth of neuritelike processes on breast cancer cells and promotes tumour growth and metastasis. Int J Cancer 135: 2338-2351, 2014.

22. Fraser SP, Diss JKJ, Chioni A-M, Mycielska ME, Pan H, Yamaci RF, Pani F, Siwy Z, Krasowska M, Grzywna Z, et al: Voltage-gated sodium channel expression and potentiation of human breast cancer metastasis. Clin Cancer Res 11: 5381-5389, 2005.

23. Brisson L, Gillet L, Calaghan S, Besson P, Le Guennec JY, Roger $\mathrm{S}$ and Gore J: $\mathrm{Na}(\mathrm{V}) 1.5$ enhances breast cancer cell invasiveness by increasing NHE1-dependent $\mathrm{H}(+)$ efflux in caveolae. Oncogene 30: 2070-2076, 2011.

24. Gillet L, Roger S, Besson P, Lecaille F, Gore J, Bougnoux P, Lalmanach $\mathrm{G}$ and Le Guennec JY: Voltage-gated sodium channel Activity promotes cysteine cathepsin-dependent invasiveness and colony growth of human cancer cells. J Biol Chem 284: 8680-8691, 2009.

25. Luqmani YA, Al Azmi A, Al Bader M, Abraham G and El Zawahri M: Modification of gene expression induced by siRNA targeting of estrogen receptor alpha in MCF7 human breast cancer cells. Int J Oncol 34: 231-242, 2009.

26. Khajah MA, Al Saleh S, Mathew PM and Luqmani YA: Differential effect of growth factors on invasion and proliferation of endocrine-resistant breast cancer cells. PLoS One 7: e41847, 2012.

27. Al Saleh S, Al Mulla F and Luqmani YA: Estrogen receptor silencing induces epithelial to mesenchymal transition in human breast cancer cells. PLoS One 6: e20610, 2011.

28. Brackenbury WJ, Calhoun JD, Chen C, Miyazaki H, Nukina N, Oyama F, Ranscht B and Isom LL: Functional reciprocity between $\mathrm{Na}^{+}$channel Nav1.6 and beta1 subunits in the coordinated regulation of excitability and neurite outgrowth. Proc Natl Acad Sci USA 107: 2283-2288, 2010.

29. Brackenbury WJ and Djamgoz MBA: Activity-dependent regulation of voltage-gated $\mathrm{Na}^{+}$channel expression in Mat-LyLu rat prostate cancer cell line. J Physiol 573: 343-356, 2006.

30. House CD, Vaske CJ, Schwartz AM, Obias V, Frank B, Luu T, Sarvazyan N, Irby R, Strausberg RL, Hales TG, et al: Voltage-gated $\mathrm{Na}^{+}$channel SCN5A is a key regulator of a gene transcriptional network that controls colon cancer invasion. Cancer Res 70: 6957-6967, 2010.

31. House CD, Wang BD, Ceniccola K, Williams R, Simaan M, Olender J, Patel V, Baptista-Hon DT, Annunziata CM, Gutkind JS, et al: Voltage-gated $\mathrm{Na}^{+}$channel activity increases colon cancer transcriptional activity and invasion via persistent MAPK signaling. Sci Rep 5: 11541, 2015.

32. Carrithers MD, Chatterjee G, Carrithers LM, Offoha R, Iheagwara U, Rahner C, Graham M and Waxman SG: Regulation of podosome formation in macrophages by a splice variant of the sodium channel SCN8A. J Biol Chem 284: 8114-8126, 2009.

33. Brisson L, Driffort V, Benoist L, Poet M, Counillon L, Antelmi E, Rubino R, Besson P, Labbal F, Chevalier S, et al: NaV1.5 Na(+) channels allosterically regulate the NHE-1 exchanger and promote the activity of breast cancer cell invadopodia. J Cell Sci 126: 4835-4842, 2013.

34. Besson P, Driffort V, Bon É, Gradek F, Chevalier S and Roger S: How do voltage-gated sodium channels enhance migration and invasiveness in cancer cells? Biochim Biophys Acta 1848: 2493-2501, 2015.

35. Brackenbury WJ: Voltage-gated sodium channels and metastatic disease. Channels (Austin) 6: 352-361, 2012.

36. Maness PF and Schachner M: Neural recognition molecules of the immunoglobulin superfamily: Signaling transducers of axon guidance and neuronal migration. Nat Neurosci 10: 19-26, 2007. 
37. Ding Y, Brackenbury WJ, Onganer PU, Montano X, Porter LM, Bates LF and Djamgoz MB: Epidermal growth factor upregulates motility of Mat-LyLu rat prostate cancer cells partially via voltage-gated $\mathrm{Na}^{+}$channel activity. J Cell Physiol 215: 77-81, 2008 .

38. Mantegazza M, Curia G, Biagini G, Ragsdale DS and Avoli M: Voltage-gated sodium channels as therapeutic targets in epilepsy and other neurological disorders. Lancet Neurol 9: 413-424, 2010.

39. Hille B: Ionic channels of excitable membranes. Cell 69: 579, 1992.

40. Crill WE: Persistent sodium current in mammalian central neurons. Annu Rev Physiol 58: 349-362, 1996.

41. Ju YK, Saint DA and Gage PW: Hypoxia increases persistent sodium current in rat ventricular myocytes. J Physiol 497 337-347, 1996.

42. Kunzelmann K: Ion channels and cancer. J Membr Biol 205 $159-173,2005$

43. Turnbull DM, Rawlins MD, Weightman D and Chadwick DW: 'Therapeutic' serum concentration of phenytoin: The influence of seizure type. J Neurol Neurosurg Psychiatry 47: 231-234, 1984.

44. Nelson M, Yang M, Dowle AA, Thomas JR and Brackenbury WJ: The sodium channel-blocking antiepileptic drug phenytoin inhibits breast tumour growth and metastasis. Mol Cancer 14: 13 , 2015.

45. Brackenbury WJ, Chioni A-M, Diss JKJ and Djamgoz MBA: The neonatal splice variant of Nav1.5 potentiates in vitro invasive behaviour of MDA-MB-231 human breast cancer cells. Breast Cancer Res Treat 101: 149-160, 2007.

46. Zucker S, Cao J and Chen WT: Critical appraisal of the use of matrix metalloproteinase inhibitors in cancer treatment. Oncogene 19: 6642-6650, 2000.

47. Gialeli C, Theocharis AD and Karamanos NK: Roles of matrix metalloproteinases in cancer progression and their pharmacological targeting. FEBS J 278: 16-27, 2011.

48. Sekton B: Matrix metalloproteinases - an overview. Rev Bras Ter Intensiva 23: 222-227, 2011

49. Gao R, Wang J, Shen Y, Lei M and Wang Z: Functional expression of voltage-gated sodium channels Nav1.5 in human breas cancer cell line MDA-MB-231. J Huazhong Univ Sci Technolog Med Sci 29: 64-67, 2009.
50. Azuma T, Yamada M, Murakita H, Nishikawa Y, Kohli Y, Yamamoto $\mathrm{K}$ and Hori $\mathrm{H}$ : Cathepsin E expressed in pancreatic cancer. Adv Exp Med Biol 362: 363-366, 1995.

51. Azuma T, Hirai M, Ito S, Yamamoto K, Taggart RT, Matsuba T, Yasukawa K, Uno K, Hayakumo T and Nakajima M: Expression of cathepsin E in pancreas: A possible tumor marker for pancreas, a preliminary report. Int J Cancer 67: 492-497, 1996.

52. Kawakubo T, Yasukochi A, Toyama T, Takahashi S, Okamoto K, Tsukuba T, Nakamura S, Ozaki Y, Nishigaki K, Yamashita H, et al: Repression of cathepsin E expression increases the risk of mammary carcinogenesis and links to poor prognosis in breast cancer. Carcinogenesis 35: 714-726, 2014.

53. Hagen NA, Fisher KM, Lapointe B, du Souich P, Chary S, Moulin D, Sellers E and Ngoc AH; Canadian Tetrodotoxin Study Group: An open-label, multi-dose efficacy and safety study of intramuscular tetrodotoxin in patients with severe cancer-related pain. J Pain Symptom Manage 34: 171-182, 2007.

54. Dib-Hajj SD, Black JA and Waxman SG: Voltage-gated sodium channels: therapeutic targets for pain. Pain Med 10: 1260-1269, 2009.

55. Clare JJ: Targeting voltage-gated sodium channels for pain therapy. Expert Opin Investig Drugs 19: 45-62, 2010.

56. Busserolles J, Alloui A, Lazdunski M and Eschalier A: Use of riluzole to treat or prevent the adverse effects of antineoplastic agents. US Patent 2013/0064775 A1. Filed: March 2, 2011; issued March 14, 2013.

57. Yip D, Le MN, Chan JLK, Lee JH, Mehnert JA, Yudd A, Kempf J, Shih WJ, Chen S and Goydos JS: A phase 0 trial of riluzole in patients with resectable stage III and IV melanoma. Clin Cancer Res 15: 3896-3902, 2009

58. Biki B, Mascha E, Moriarty DC, Fitzpatrick JM, Sessler DI and Buggy DJ: Anesthetic technique for radical prostatectomy surgery affects cancer recurrence: A retrospective analysis. Anesthesiology 109: 180-187, 2008.

59. Mao L, Lin S and Lin J: The effects of anesthetics on tumor progression. Int J Physiol Pathophysiol Pharmacol 5: 1-10, 2013. 